УДК 616.21-002.1-053.2-07

\title{
С.А. Левицька,
}

О.М. Понич*,

O.Г. Спiвак*,

Г.C. Спiвак*

Буковинський державний медичний

університет, м. Чернівці

Чернівецька міська лікарня №2*

Ключові слова: гнійний синуїт, діти, щзо часто та тривало хворіють

\section{ДІАГНОСТУВАННЯ ГНІЙНОГО СИНУЇТУ В ДІТЕЙ, ЩО ЧАСТО ТА ТРИВАЛО ХВOPIЮTЬ}

\begin{abstract}
клінічних діагностичних показників мали високу чутливість $i$ низьку специфічність. Гострий гнійний синуїт діагностували в кожного п'ятого дошкільняти та більше, ніж у 40\% школярів групи спостереження. Для зменшення помилок при діагностуванні гнійного синуїту у дітей, щуо часто тривало хворіють, дочуільним є проведення рентгенологічного дослідження біляносових пазух.
\end{abstract}

\section{Вступ}

Проблема діагностики гнійного синуїту (ГС) у дітей не втратила своєї актуальності, оскільки й досі немає єдиного й універсального методу, який би дозволяв безпомилково встановити діагноз ГС [5]. Труднощі діагностики у дітей, що часто та тривало хворіють (ДЧТХ), зумовлені тим, що гнійне враження біляносових пазух (БНП) може "маскуватися" черговим тривалим епізодом гострої респіраторної вірусної інфекції (ГРВІ) [4]. Адже клінічні симптоми ГС подібні до симптомів ГРВI, а розвиток ГС безпосередньо пов'язаний 3 перенесеним ГРВІ [1].

\section{Мета дослідження}

Підвищити ефективність діагностики ГС серед ЧТХД за рахунок визначення діагностичної значимості клінічних показників і результатів рентгенологічного дослідження.

\section{Матеріал та методи}

Діагностична значущість клінічних показників ГРВІ і ГС була проведена у 102 дітей із клінічними ознаками ГРВІ. Умовами включення в дослідження були: тривалість даного епізоду ГРВІ (більше 5 днів), вік дитини (від 3 до 15 років), тривалість відвідування організованих дитячих колективів (більше 1 року), частота ГРВІ (більше 5 за останній рік), відсутність анамнестичних вказівок на хронічні запальні захворювання верхніх і нижніх дихальних шляхів (хронічний синуїт, хронічний бронхіт, бронхіальна астма).

Критеріями діагностування ГС було рентгенологічне зниження пневматизації біляносових пазух (БНП) у вигляді гомогенного затемнення чи затемнення із горизонтальним рівнем рідини i/ або знаходження в носових ходах умовно патогенної мікрофлори із загальним популяційним рівнем більше 5,0 $\operatorname{lgКУО/мл.~}$

Для діагностичних критеріїв вираховувалися чутливість, специфічність, відношення правдоподібності і прогностична цінність позитивного та негативного результатів [2]. Статистична обробка отриманих результатів проводилася за допомогою програми "БІОСТАТ". Оскільки критерії, що вивчалися, відносилися до якісних, за статистичний критерій обраний 2 [3].

\section{Обговорення результатів дослідження}

Гострий гнійний запальний процес в БНП був підтверджений у 36 дітей, які склали першу групу. В другу групу ввійшли 66 дітей, у яких за результатами проведеного дослідження, діагноз ГС був спростований.

Найчастішими клінічними симптомами у дітей обох груп були утруднення носового дихання $(94,4 \%$ та 93,9 \% в першій та другій групах відповідно), головний біль (72,2 \% і 66,7 \%), слизово-гнійні виділення з носа (77,8 \% і 57,6 \%), підвищення температури тіла (41,7\% і 57,6 \%), слизово-гнійні виділення на дні носової порожнини та в носоглотці $(77,8 \%$ i $69,7 \%)$.

У той же час такі симптоми, як гнійні виді- 
лення в середньому носовому ході у вигляді смужки гною (38,9\% і 3,0\%), а також болючість при пальпації та перкусії передніх стінок БНП (47,2 \% і 6,1 \%) зустрічалися майже виключно в дітей першої групи (табл. 1).

Аналіз результатів дослідження засвідчив, що проведення диференційної діагностики чергового епізоду ГРВІ і ГС на підставі виключно клінічних показників викликає певні труднощі. Адже більшість симптомів, такі як утруднення носового дихання, слизово-гнійні виділення з носа, головний біль, однаково часто зустрічалися в обох групах спостереження. Більш інформативними для діагностування гнійного враження БНП виявилися наявність смужки гною в середньому носовому ході, а також болючість при пальпації БНП. Проте і ці, характерні для ГС симптоми, зустрічалися не більше, ніж у половини дітей першої групи (табл. 1).

Більшість клінічних показників показала високу чутливість, проте низьку специфічність (табл. 2). Низька прогностична цінність позитивного результату дозволяє стверджувати, що назальна обструкція, головний біль, слизово-гнійні виділення з носа і носоглотки, підвищення температури тіла не є достатніми аргументами для виставлення діагнозу ГС у дитини.

Високоспецифічними діагностичними показниками виявилися гнійні виділення у вигляді смужки гною в середньому носовому ході і болючість при пальпації БНП (табл. 2). Проте, низька чутливість даних показників (38,9 \% i 47,2\% відповідно) не дозволяє спростувати наявність ГС у дитини за їх відсутності.

За показниками відношення правдоподібності позитивного і негативного результатів відсутність назальної обструкції у дитини з ГРВІ є вагомим аргументом, що спростовує враження БНП (RR$=15,7)$, в той час як болючість при пальпації БНП $(\mathrm{RR}+=7,8)$ і смужка гною в середньому носовому ходi $(\mathrm{RR}+=12,8) \in$ інформативними доказами на користь ГС (табл.2).

При аналізі вікового складу обстежуваних груп виявили, що найменша частота ГС характерна для дошкільного віку $(21,4 \%)$, в той час як у старших вікових групах відсоток виявлення ГС серед обстежуваних вірогідно вищий і складає 43,8 \% для молодшого шкільного віку і 46,4% для середнього шкільного віку (табл. 3).

Отже, ймовірність виникнення гнійного синуїту у дітей, що часто та тривало хворіють, більша у дітей молодшого та середнього шкільного віку в порівнянні з дошкільнятами. порівнянні з дошкільнятами.

\section{Висновки}

1.Подібність клінічних ознак гнійного синуїту i респіраторної вірусної інфекції у дітей, що часто та тривало хворіють, зумовлює труднощі в диференційній діагностиці. Більшість клінічних діагностичних критеріїв виявилася високочутливою, але низько специфічною.

2.Необхідною складовою діагностичного алгоритму гнійного синуїту повинно бути рентгенологічне дослідження. Гнійне враження біляносових пазух не буде вчасно розпізнано приблизно у 30 \% дітей, що часто та тривало хворіють, якщо діагностичними критеріями будуть виключно клінічні ознаки.

3.Частота виявлення гнійного синуїту вища у старших вікових групах. Гострий гнійний синуїт діагностується у кожного п'ятого дошкільняти та

Таблиця 1

Результати оцінки клінічних симптомів серед груп спостереження

\begin{tabular}{|c|c|c|c|}
\hline Клінічний симптом & $\begin{array}{c}\text { Перша група } \\
(\mathrm{n}=36)\end{array}$ & $\begin{array}{l}\text { Друга група } \\
(\mathrm{n}=66)\end{array}$ & $\begin{array}{l}\text { Статистична } \\
\text { обробка }\end{array}$ \\
\hline Утруднення носового дихання & 34 & 62 & $\chi^{2}=0,01 ; v=1 ; p=0,92$ \\
\hline Головний біль & 26 & 44 & $\chi^{2}=0,33 ; v=1 ; p=0,56$ \\
\hline $\begin{array}{l}\text { Слизисто-гнійні чи гнійні } \\
\text { виділення з носа }\end{array}$ & 28 & 38 & $\chi^{2}=4,16 ; v=1 ; p=0,04$ \\
\hline Підвищення температури тіла & 15 & 38 & $\chi^{2}=2,36 ; v=1 ; p=0,12$ \\
\hline $\begin{array}{l}\text { Гнійні виділення в середньому } \\
\text { носовому ході у вигляді смужки } \\
\text { гною }\end{array}$ & $14^{*}$ & $2^{*}$ & $\chi^{2}=22,65 ; v=1 ; p=0,0$ \\
\hline $\begin{array}{l}\text { Слизово-гнійні виділення на дні } \\
\text { носової порожнини та в } \\
\text { носоглотці }\end{array}$ & 28 & 46 & $\chi^{2}=0,76 ; v=1 ; p=0,38$ \\
\hline $\begin{array}{l}\text { Болючість при пальпації та } \\
\text { перкусії передніх стінок БНП }\end{array}$ & $17^{*}$ & $4^{*}$ & $\chi^{2}=24,14 ; \nu=1 ; p=0,0$ \\
\hline
\end{tabular}

Примітка: * - різниця в розподілі показника достовірна 
Чутливість та специфічність діагностичних тестів

Таблиця 2

\begin{tabular}{|c|c|c|c|c|c|c|c|}
\hline №пI & Тест & Se & Sp & + PV & -PV & RR+ & RR- \\
\hline 1. & Утруднення носового дихання & $94,4 \%$ & $6,1 \%$ & $35,4 \%$ & $33,3 \%$ & 1,0 & 15,7 \\
\hline 2. & Головний біль & $72,2 \%$ & $33,3 \%$ & $37,1 \%$ & $31,3 \%$ & 1,1 & 2,2 \\
\hline 3. & $\begin{array}{c}\text { Слизисто-гнійні чи гнійні } \\
\text { виділення з носа }\end{array}$ & $77,7 \%$ & $42,4 \%$ & $42,4 \%$ & $22,2 \%$ & 1,4 & 1,9 \\
\hline 4. & Підвищення температури тіла & $44,4 \%$ & $42,4 \%$ & $28,3 \%$ & $42,9 \%$ & 0,7 & 1,0 \\
\hline 5. & $\begin{array}{c}\text { Гнійні виділення в середньому } \\
\text { носовому ході у вигляді смужки } \\
\text { гною }\end{array}$ & $38,9 \%$ & $97,0 \%$ & $87,5 \%$ & $25,6 \%$ & 12,8 & 0,4 \\
\hline 6. & $\begin{array}{c}\text { Слизово-гнійні виділення на дні } \\
\text { носової порожнини та в } \\
\text { носоглотці }\end{array}$ & $77,8 \%$ & $30,3 \%$ & $37,8 \%$ & $28,6 \%$ & 2,6 & 2,6 \\
\hline 7. & $\begin{array}{c}\text { Болючість при пальпації та } \\
\text { перкусії передніх стінок БНП }\end{array}$ & $47,2 \%$ & $94,0 \%$ & $81,0 \%$ & $23,5 \%$ & 7,8 & 0,5 \\
\hline
\end{tabular}

Примітка: Se - чутливість тесту, Sp - специфічність тесту, +PV - прогностична цінність позитивного результату, -PV - прогностична цінність від'ємного результату, $+\mathrm{RR}$ - відношення правдоподібності позитивного результату, -RR - відношення правдоподібності від’ємного результату

Частота діагностування ГС залежно від віку

\begin{tabular}{|c|c|c|}
\hline Вік & Перша група $(\mathbf{n = 3 6 )}$ & Друга група (n=66) \\
\hline 3-6 років $(\mathrm{n}=42)$ & $9(21,4 \%)$ & $33(78,6 \%)$ \\
\hline 6-9 років $(\mathrm{n}=32)$ & $14(43,8 \%)$ & $18(56,2 \%)$ \\
\hline 9-15 років $(\mathrm{n}=28)$ & $13(46,4 \%)$ & $15(53,6 \%)$ \\
\hline
\end{tabular}

більше ніж у 40 \% школярів, що часто та тривало хворіють.

\section{Перспективи подальших досліджень}

Подальше вдосконалення діагностики ГС у дітей дозволить покращити якість лікування, зменшити відсоток інвазійних втручань, знизити кількість риногенних ускладнень.

Література. 1. Тімен Г.Е. Діагностика і лікування гострого верхньощелепного синуситу у дітей / Г.Е.Тімен // Мистецтво лікування. - 2004. - №1(007). - С.24-27. 2. Флетчер Р. Клиническая эпидемиология. Основы доказательной медицины / Р.Флетчер, С.Флетчер, Э.Вагнер; пер с англ. Ю.Б.Шевелева. - М.МедиаСфера, 3-е изд., 2004. 352 с., ил. 3. Халафян А.A. Statistica 6. Статистический анализ данных. 3-е изд. Учебник / Халафян А.А. - М.: ООО "Бином-Пресс", 2007. - 512 с., ил. 4. Часто болеющие дети: современная фармакотерапия / М.Г.Романцов, Ф.И.Ершов / Руководство для врачей // Москва, "ГЭОТАР-Медиа". 196 c. 5. Chlabicz S. Respiratory tract infections: diagnosis and use of antibiotics by family physicians in north-eastern Poland / S.Chlabicz, A.Malgorzata-Oltarzewska, B.Pytel-Krolczuk // Int J Antimicrob Agents. - 2004. - Vol. 23, №5. - P.446-450.

\section{ДИАГНОСТИКА ГНОЙНОГО СИНУСИТА У ЧАСТО И ДЛИТЕЛЬНО БОЛЕЮЩИХ ДЕТЕЙ}

\section{С.А. Левицкая, А.Н. Понич, А.Г. Спивак, Г.С. Спивак}

Резюме. Проведено исследование основных клинических показателей гнойного синусита у 102 детей, которые подвержены острым респираторным заболеваниям. Установлено, что большинство клинических диагностических показателей имели высокую чувствительность и низкую специфичность. Острый гнойный синусит диагностировали у каждого пятого дошкольника и более чем у 40 \% школьников группы наблюдения. Для уменьшения доли ошибок при диагностировании гнойного синусита у часто и длительно болеющих детей целесообразным является проведение рентгенологического исследования около-носовых пазух.

Ключевые слова: гнойный синусит, часто и длительно болеющие дети.

\section{DIAGNOSTICS OF PURULENT SINUSITIS IN CHILDREN WHO ARE AILING}

\section{S.A. Levytska, O.M. Ponych, O.G. Spivak, G.S. Spivak}

Abstract. The analysis of the main clinical indices of purulent sinusitis has been studied in 102 children who are ailing with acute respiratory diseases. It has been established, that the majority of clinical indices had high sensitiveness and low specificity. The acute purulent sinusitis was diagnosed in every fifth preschool child and more than $40 \%$ school-age children. The X-ray examination of paranasal sinuses is expediently for decreasing the part of mistakes in diagnostics of purulent sinusitis in children who are in poor health. health.

Key words: purulent sinusitis, children who are in poor

Bukovyna State Medical University (Chernivtsi)

Clin. and experim. pathol.- 2014.- Vol.13, №1 (47).-P.78-80.

Надійила до редакиії 15.03.2014

Речензент - проф. Сидорчук І.Й.

(С).А. Левицька, О.М. Понич, О.Г. Співак, Г.С. Співак, 2014 